AC 2010-1560: YOUNG MINDS MEET FOR SUSTAINABLE FUTURE

Faruk Yildiz, Sam Houston State University

Recayi "Reg" Pecen, University of Northern Iowa

Soner Tarim, Cosmos Foundation dba Harmony Schools 


\title{
Young Minds Meet for Sustainable Future
}

\begin{abstract}
The Sustainability is the intent to provide the best outcomes for the human and natural environments both now and indefinite future. The Sustainability relates to the continuity of economic, social, institutional and environmental aspects of human society, as well as the nonhuman environment. The Cosmos Foundation, a non-profit educational organization with 19 campuses and more than 7000 students all over the Texas took an initiative tour toward global awareness. The Cosmos foundation organizes an annual transformative International Science Fair Olympiad called I-SWEEEP (International Sustainable World Energy Engineering \& Environment Project Olympiad) since 2008. The Cosmos Foundation brings the best and brightest students from all over the world to Houston, Texas to demonstrate their selected research findings. This paper describes how this Olympiad engages young minds in a search for solutions to the environmental and energy related challenges of today in hopes of achieving a sustainable world for tomorrow. The I-SWEEEP stimulates students' interest in practical solutions and cultivates the future of the energy frontier through unique projects. The mission of I-SWEEEP is to create a collaborative yet competitive environment in which students can present their innovative ideas/projects to solve today's challenges in energy, engineering, and environment, which will ensure a sustainable world for tomorrow. All the judges for the project evaluations are selected from academia and industrial professionals. The judging process gives a good opportunity to engineering professionals and academicians to review and evaluate what prospective engineers have developed for a sustainable future. The I-SWEEEP promotes engineering inventions and energy efficiency/management discoveries, which nurture ecofriendly technology concepts in K-12 STEM education.
\end{abstract}

\section{Introduction}

According to the National Science Board (NSB)'s Science and Engineering Indicators 2004, enrollment in undergraduate engineering and science programs in the United States has been in decline since the $1980 \mathrm{~s}^{1}$. Clearly, there is a continued need for increased enrollment and retention in science and engineering. Science, Technology, Engineering, and Mathematics (STEM) have become increasingly central to our economic competitiveness and growth. Longterm strategies to maintain and increase living standards and promote opportunity will require unprecedented coordinated efforts among public, private, and non-profit entities to promote innovation and to prepare an adequate supply of qualified STEM workers ${ }^{1}$. STEM education has become increasingly central to U.S. economic competitiveness and growth. Long-term strategies to maintain and increase living standards and promote opportunity will require unprecedented coordinated efforts among public, private, and non-profit entities to promote innovation and to prepare an adequate supply of qualified STEM workers that are capable of translating knowledge and skills into new processes, products, and services ${ }^{1-7}$.

The International Sustainable World Energy, Engineering, and Environment Project (ISWEEEP) Olympiad, is a groundbreaking science fair open to middle and high school students. It is one of the largest science fair events of its kind world-wide. Similarly, Intel Corporation has been conducting International Science and Engineering Fair since $1992^{8}$. The I-SWEEEP is organized by the Cosmos Foundation, a non-profit educational organization in Houston, TX with 
a mission to establish college preparatory K-12 schools focusing on math, science, engineering, and computer technologies in an effort to provide a world-class education to public. The Cosmos Foundation currently operates 19 high performing public STEM schools in Texas. I-SWEEEP works with local, national, and international science fair organizations to bring together the topranking participants and qualifying projects from these competitions. This prestigious event has been organized with the support of K-12 public school systems, leaders of industry, State of Texas Department of Education, and higher education institutions. It creates an intellectual pipeline for energy, engineering, and environmental related careers and invites students into these important areas of the workforce. An awareness was created among students to prepare themselves as future scientists and engineers who have great understanding of global issues and to tackle the challenges to maintain global sustainability.

The I-SWEEEP mobilizes many national and international science fair organizations, school districts, higher education institutions, and industrial organizations to work together towards the sustainable world. These events promote renewable energy, energy efficiency, energy management, and clean energy technology concepts in K-12 education. The mission of ISWEEEP is to accelerate the progress to a sustainable world by engaging young minds early on. This gives an opportunity for secondary school students to prepare themselves as future engineers who have a greater understanding of global issues and energy problems. The goal is to stimulate the interest in building a more sustainable world among young engineers of the future. There is now growing awareness on the brewing energy crisis facing mankind which marks a distinct departure from past trends to new patterns of energy production and use. Another mission is to promote interest in solving energy related problems in all over the world among young students.

In this Olympiad the young students compete to develop an environmentally conscious and responsible community, and to inspire others in caring for the environment. Pictures from senior award ceremony, demonstration and registration floor, judging, and the opening ceremony are shown in Figure 1.

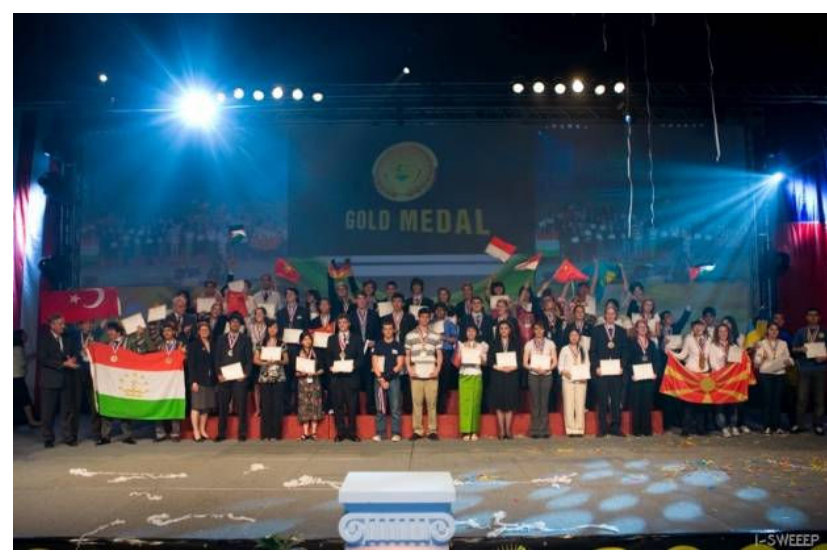

a) senior award ceremony

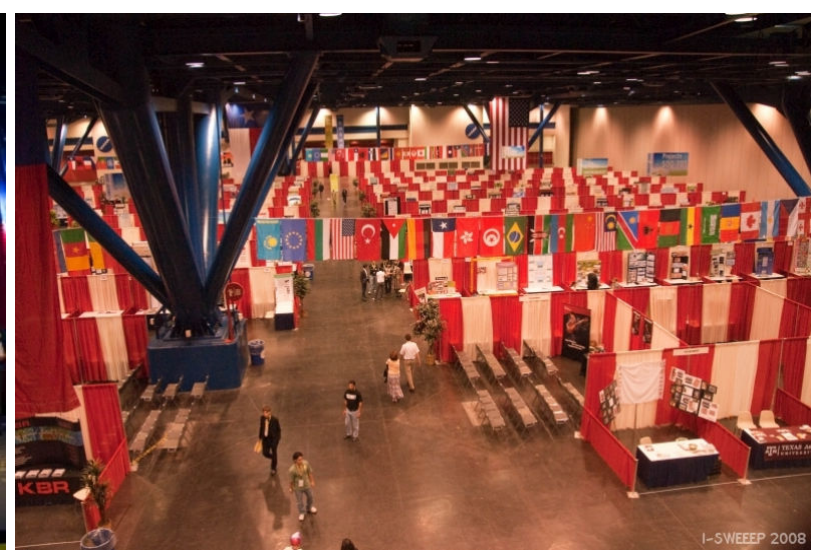

b) demonstration and registration floor 


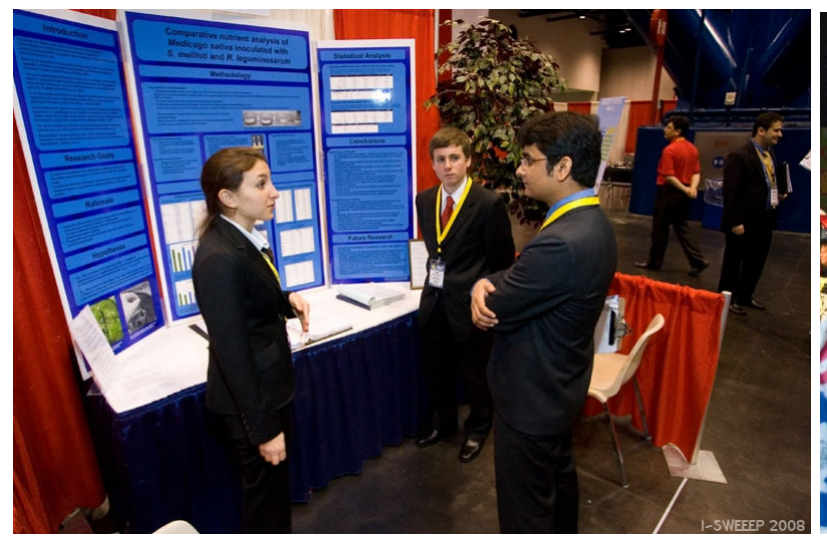

c) judging

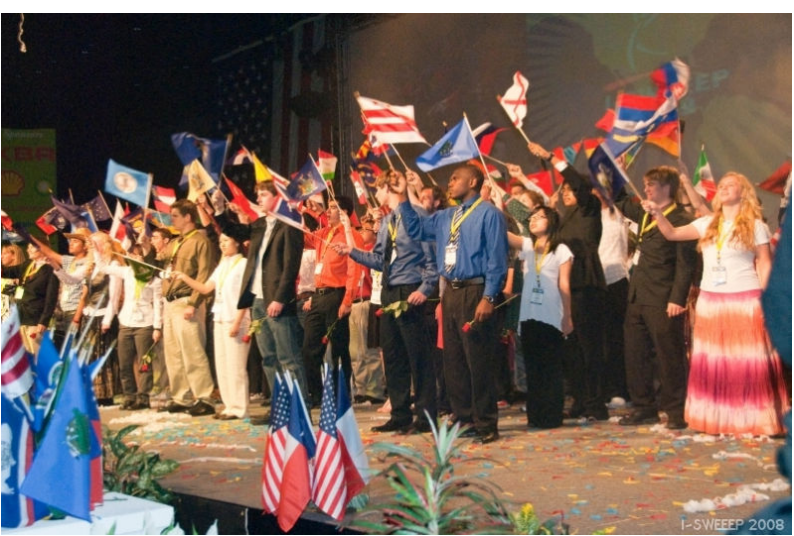

d) the opening ceremony

Figure 1. The I-SWEEEP Olympiad 2009 event pictures

\section{Objectives}

The purpose of this Olympiad is to engage young students in a search for solutions to the environmental and energy related challenges of today in hopes of achieving a sustainable world for tomorrow. I-SWEEEP stimulates students' interest in practical solutions and cultivates the future of the energy frontier through unique projects. The mission of this event is to create a collaborative yet competitive environment in which students can present their innovative ideas/projects to solve today's challenges in energy, engineering, and environment, which will ensure a sustainable world for tomorrow. Mission and purpose can be summarized as follows:

- Spark interest and awareness in our planet's sustainability challenges

- Help young people grasp the extent of these issues

- Find workable solutions to these challenges

- Accelerate the progress toward a sustainable world by engaging youths at an early age

- Plays an integral role in bringing industry, K-12, and higher education together

- Raises public awareness regarding the 3 Es (Energy, Environment, and Engineering) for a sustainable world

- Guides the brightest minds into these three important areas of the workforce

- Creates an intellectual pipeline for 3 Es related careers

The I-SWEEEP also promotes engineering inventions and energy efficiency/management discoveries, which will nurture environment-friendly technology concepts in secondary education. It gives secondary-school students the opportunity to position themselves to be the pre-imminent scientists and engineers of the future. It will be these individuals who have a greater understanding of global issues and the importance of technology in achieving global sustainability that will be at the forefront of environmental research and development. This event is a pivotal step in our educational efforts to develop an environmentally conscious global community and to inspire personal responsibility in caring for the planet and those who share it.

\section{Rules and Guidelines}

Understanding the rules and guidelines of the I-SWEEEP and properly completing all of the paperwork are essential and necessary parts of completing applicant's research projects. For this 
reason, I-SWEEP strongly recommends that student must read thoroughly the rules and guidelines which is updated regularly, and correctly file all necessary paperwork. In steps of a scientific research, the researchers must maintain integrity. Researchers should avoid any scientific misconduct such as falsifying data, plagiarism, or using the works of other researchers. Such projects fail to compete in the I-SWEEEP Olympiad.

\subsection{Eligibility}

Secondary and High school students (grades 6 through 12) display their research projects at ISWEEEP in the areas of Energy, Engineering, and Environment. There are two divisions at the ISWEEEP fair which are the Junior Division and the Senior Division. The Junior Division is only open to U.S. students attending classes in grades 6 through 8. The Senior Division is open to both U.S. and international students attending classes in grades 9 through 12. The eligibility of the applications are considered in three categories.

Direct Qualification from Regional, State, or National Science Fairs: A limited number of projects directly qualify from Regional, State, or National Science Fairs. Those projects are judged by the fair organizations and get qualified for I-SWEEEP. While all applications are subject to pre-elimination process, those projects forgo such screening by I-SWEEEP's Scientific Review Committee.

Recognition from Regional, State, or National Science Fairs: Additionally, some projects are recognized and nominated for the I-SWEEEP by various fair organizations. This recognition does not guarantee the spot at the event. The I-SWEEEP's scientific review committee evaluates the projects and notifies the students of their eligibility to participate in this event after factoring in the recognition from fair organizations.

Individual Applications: The students can apply individually. Students are highly encouraged to compete in a regional, state, or national science fairs prior to the I-SWEEEP, if possible.

Scientific Review Committee evaluates the projects and notifies the students of their eligibility to participate in the I-SWEEEP.

\subsection{Registration}

Registration process is one of the long processes in this international event due to state and federal requirements. Organization committee gives special attention to this process to make sure every participant demonstrates his/her project in the event without any registration problem. Participants go through some registration steps by the help of either online resources or email communications. Anyone participating in the fair must register. A contestant or a group of contestants should be accompanied by an adult supervisor (parent, teacher, or project supervisor) during the event. Contestants and adult supervisors should work together to complete the registration process. Contestants should register their projects and submit the abstracts online. If participants' project requires risk management form, this form should be filled out by project supervisor (the person who provided the most assistance for participant's research). 


\section{Facts and Success Stories}

Second annual I-SWEEEP Olympiad was held in April, 2009 in Houston, TX with a very high number of participation from all over the world. The statistical information in Table 1 is given according to the I-SWEEEP 2009 Olympiad. The information about I-SWEEP 2008 is available on the organization website ${ }^{9}$. Table 1 has extensive information about the I-SWEEEP $2009^{10}$.

Table 1. I-SWEEEP 2009 Facts.

\begin{tabular}{|l|l|}
\hline Number of Participated Countries: & 60 \\
\hline Number of States represented: & 40 \\
\hline Total Number of Projects: & 452 \\
\hline The Number of Projects in Junior Division (Only US middle schools): & 90 \\
\hline The Number of Projects in Senior Division: & 360 \\
\hline Total International Projects: & 135 \\
\hline Total US Projects: & 315 \\
\hline Number of Students: & 660 \\
\hline Number of Teachers: & 360 \\
\hline Number of Judges: & 220 \\
\hline Number of Volunteers: & 415 \\
\hline
\end{tabular}

Over 1000 claimed researchers for more than 60 countries and 40 U.S. States have participated in this event. In 2009 event's final round 452 research projects were selected complete out of thousand of applications from all over the world. Figure 2 shows the percentages of overall projects from 452 selected finalist projects among 1621 project applications from 72 countries.

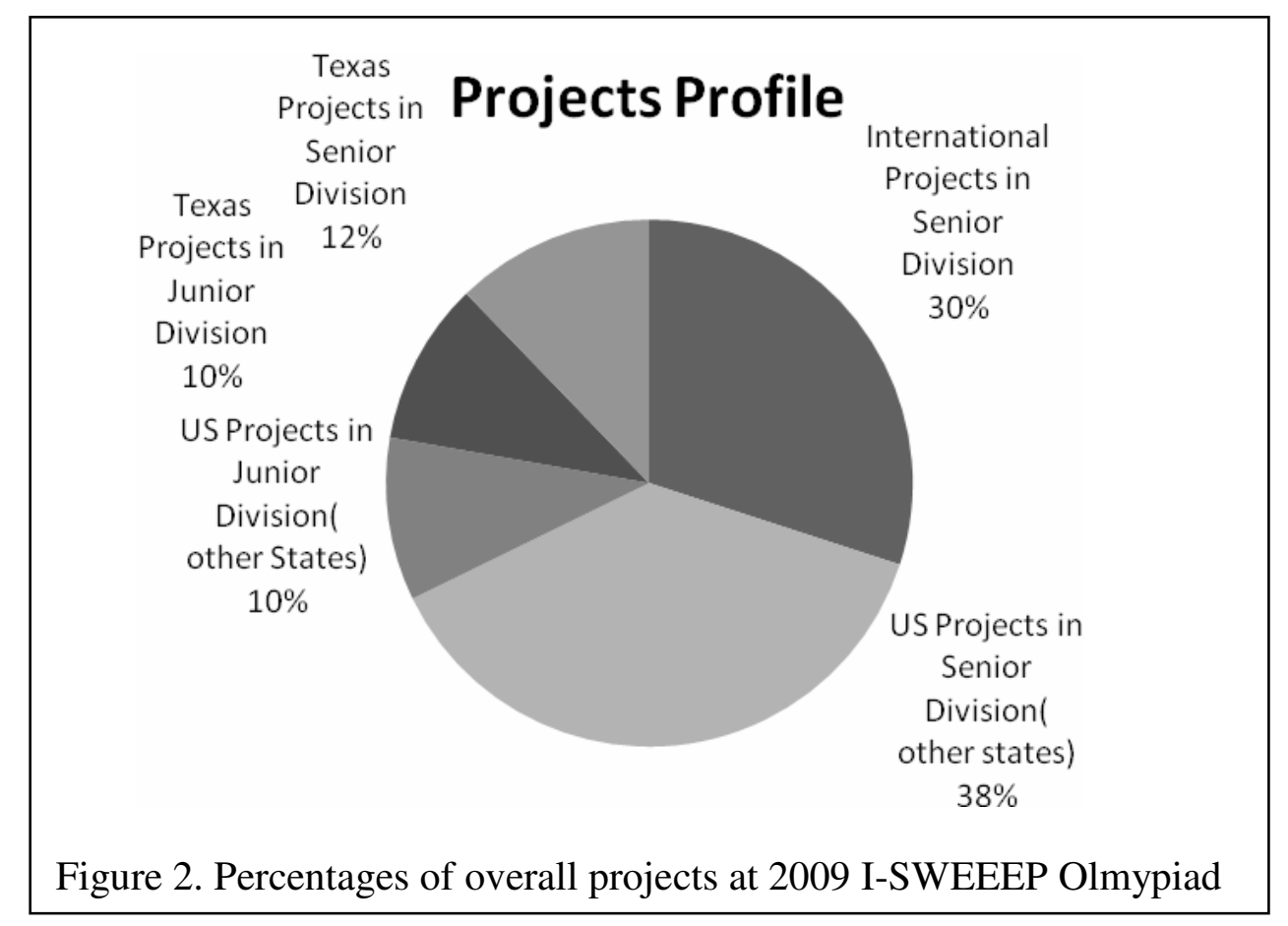


During the 2009 Olympiad, $74 \%$ of finalist projects were awarded gold, silver, bronze medals, and honorable mention certificates. The Organizing Committee awarded the winners generously. The I-SWEEEP Organization awards are valued at nearly $\$ 170,000$ in monetary prizes. Also, special award agencies including the most prestigious universities in Texas and corporate companies awarded finalist students. The I-SWEEEP Special Awards are valued at nearly $\$ 231,000$ in scholarships, monetary prizes, tuition grants, and scientific internships. Total financial awards provided to category winners by Organizing Committee were $\$ 170,000$. Table 2 shows award information.

Table 2. Awards Distribution at 2009 I-SWEEEP Olympiad

\begin{tabular}{|l|r|r|}
\hline Medal & Percentage & \multicolumn{1}{|l|}{ Award } \\
\hline Gold & $10.20 \%$ & $\$ 1000$ \\
\hline Silver & $19.33 \%$ & $\$ 750$ \\
\hline Bronze & $26.44 \%$ & $\$ 500$ \\
\hline Honorable Mention & $18.22 \%$ & $\$ 300$ \\
\hline Total Awarded Project Percentile & $\mathbf{7 4 . 1 9 \%}$ & \\
& & \\
\hline
\end{tabular}

Some of colleges offered college scholarships and special awards to students participated to ISWEEEP Olympiad. The I-SWEEEP Special Awards are valued at nearly $\$ 231,000$ in scholarships, monetary prizes, tuition grants, and scientific internships. The list of colleges and special awarding agencies provided scholarships is given below.

Colleges provided Scholarships,

- University of Texas at Austin

- Texas A\&M university

- University of Houston

- Louisiana State University

- Oklahoma Christian University

- Lamar University

- Texas A\&M University-Commerce

- The University of Texas at Arlington

- Texas Christian University

- Texas Wesleyan University

- The University of Texas at San Antonio

Some of Special Awarding Agencies,

- Texas Center for Superconductivity at the University of Houston

- Houston Advanced Research Center 
- Shell

- BP

- Houston Technology Center

- The Office of Naval Research

- Texas Department of Transportation

I-SWEEEP sponsors are forward-thinking energy companies, state/private institutions and leaders who provide cutting edge technology and services. Sponsorship of this unmatched event provides sponsors an exceptional opportunity to:

- Connect with over 1,000 bright minds who are prospective energy researchers

- Network with leading figures of energy research from academia

- Increase PR visibility

- Publicly acknowledge company pledge to the role of education in the future of energy industry

- Position their business as a dynamic, talent-friendly company

- Expand and strengthen their position as a leader in the field

- Gain exposure for marketing message, product launch or display

- Align company with the like-minded ideology of future excellence

- Publicize the benefits of a career in their industry and assist in the development of future leaders

- Contribute to global sustainability studies

Companies/institutions are offered one or more of the following sponsorship types. All sponsorship types provide attention to company/institution and its logo on various signage and pre and post publications and marketing materials.

Official Sponsorships: Organization achieves the maximum impact by choosing from one of ISWEEEP's five sponsorship levels: main, diamond, platinum, gold, and silver.

Customized Sponsorships: Customized sponsorship packages provide a variety of signage opportunities on/in show items such as event bags, T-shirts, receptions, and ceremonies. College Scholarships: This opportunity is open to colleges and universities only and provides scholarships for prospective students.

\section{Categories}

In each division, students compete in three different categories: Energy, Engineering, and Environment. These are subcategories in each category; I-SWEEEP upholds the 3E (energy, engineering, and environment) concept in all of its events. Academic competition categories and subcategories are outlined in Table 3.

Table 3. Project Categories.

\begin{tabular}{|l|l|l|}
\hline Energy & Engineering & Environment \\
\hline Renewable Energy & Biological Engineering & Land Management \\
\hline Bio Energy & Civil Engineering & Ecosystem Management \\
\hline Non-Renewable Energy- & Mechanical Engineering & Bioremediation \\
\hline
\end{tabular}




\begin{tabular}{|l|l|l|}
\hline Clean, Green Advancements & & \\
\hline Energy Policies & Industrial Engineering & Air Pollution/Quality \\
\hline Clean Energy Technology & Material Science & Soil Pollution/Quality \\
\hline Energy Efficiency & Electrical Engineering & Water Pollution/Quality \\
\hline Energy Conservation & Computer Engineering & 3R:Reduce-Reycle-Reuse \\
\hline
\end{tabular}

\section{Review and Evaluation Process}

There were 220 judges who have volunteered to be part of the I-SWEEEP 2009. The organizing committee successfully recruited qualified judges to evaluate the research projects of the participants. Research projects are evaluated based on scientific thought, originality, understanding, the exhibit, and presentations. The I-SWEEEP judges come from various backgrounds and professions. Judges include, but are not limited to science, engineering, and industry professionals, recognized experts in their field of study, dedicated researchers, professors, post-docs, educators and scientists. When judges evaluate the projects, they mostly focus on specific areas provided by a review committee that is shown in Table 4. Qualified scientists, engineers, professors, postdocs, graduate students, specialists, researchers, and other professionals can be part of judging committees according to their background and interests to evaluate research projects of young scientist. Online registration is required in order to qualify as a judge in the fair. I-SWEEEP provides fair schedule, judging criteria and relevant information by email communications to make sure every judge understands the judging process. The grade points of each criterion for judging process is shown in Table 5.

Table 4. Project Evaluation Questions.

\begin{tabular}{|l|l|}
\hline Main Questions & Sub-Questions \\
\hline $\begin{array}{l}\text { Were you creative when doing your } \\
\text { science fair project? }\end{array}$ & $\begin{array}{l}\text { Does your research show creativity and originality? } \\
\text { Did you solve the question in an original way? } \\
\text { Did you construct or design new equipment? }\end{array}$ \\
\hline $\begin{array}{l}\text { Did you follow the scientific methods } \\
\text { and procedures in your science fair } \\
\text { project? }\end{array}$ & $\begin{array}{l}\text { Did you clearly state your problem? } \\
\text { Did you use scientific literature when you do your } \\
\text { initial research? } \\
\text { Did you clearly state your variables? } \\
\text { Did you use controls? } \\
\text { Does your data support your conclusions? } \\
\text { Do you recognize the limitations of the data / } \\
\text { experiment? And did you state them in your } \\
\text { conclusions? } \\
\text { Did you make suggestions as to what further research is } \\
\text { warranted? }\end{array}$ \\
\hline $\begin{array}{l}\text { Were you thorough in doing your } \\
\text { science project? }\end{array}$ & $\begin{array}{l}\text { Did you carefully think out your science fair project, } \\
\text { go about it systematically for simple science fair } \\
\text { projects with well thought-out research following the } \\
\text { scientific method for kids outline and observations? } \\
\text { Did you complete all parts of your research }\end{array}$ \\
\hline
\end{tabular}




\begin{tabular}{|l|l|}
\hline & $\begin{array}{l}\text { experiment? } \\
\text { Did you keep a project journal? } \\
\text { Did you keep detailed notes in your journal? }\end{array}$ \\
\hline $\begin{array}{l}\text { What was the quality of your } \\
\text { technical skill? }\end{array}$ & $\begin{array}{l}\text { Did you have the required equipment to obtain your } \\
\text { data? } \\
\text { Was the project performed at home, school, university } \\
\text { laboratory? } \\
\text { Where did the equipment come from? Did you build it? } \\
\text { Did you loan it from somewhere? Did you work in a } \\
\text { professional laboratory? } \\
\text { Did you do the project yourself or did you receive } \\
\text { help? If you received help the judges are looking for } \\
\text { you to give credit to those individuals. }\end{array}$ \\
\hline $\begin{array}{l}\text { Did you have clarity with the details } \\
\text { of your science project? }\end{array}$ & \\
\hline $\begin{array}{l}\text { How well your project fits in with the } \\
\text { theme of being beneficial to society } \\
\text { will be taken into account? }\end{array}$ & \\
\hline
\end{tabular}

Table 5. Grades points of judging criteria.

\begin{tabular}{|l|l|l|}
\hline CRITERIA & POINT & EXPLANATION \\
\hline Creativity/Originality & 5 & $\begin{array}{l}\text { Originality of the problem; unique approach to } \\
\text { solve a sustainability issue. }\end{array}$ \\
\hline Review of Literature & 5 & $\begin{array}{l}\text { Research of scientific literature and use of } \\
\text { references. }\end{array}$ \\
\hline Scientific Thought & 5 & $\begin{array}{l}\text { Statement of hypothesis; clarity of purpose; } \\
\text { identification of all relevant variables. }\end{array}$ \\
\hline Scientific Method & 5 & $\begin{array}{l}\text { Evidence of depth of study and effort in employing } \\
\text { scientific procedures; proper methods followed for } \\
\text { experimentation and investigations. }\end{array}$ \\
\hline Data Management & 5 & $\begin{array}{l}\text { Proper recording and display of data in tables, } \\
\text { charts, and graphs; proper analysis of data. }\end{array}$ \\
\hline Conclusions & 5 & $\begin{array}{l}\text { Drawing logical conclusions, consistency of } \\
\text { conclusions with obtained data; recommendations } \\
\text { for further research. }\end{array}$ \\
\hline Applications & 5 & $\begin{array}{l}\text { Practical applications of the project; benefits for } \\
\text { society in certain ways. }\end{array}$ \\
\hline $\begin{array}{l}\text { Research Skills and } \\
\text { Effort }\end{array}$ & 5 & $\begin{array}{l}\text { Level of skills and effort by (each) researcher to } \\
\text { carry out the project; amount of work; high level of } \\
\text { understanding of the techniques and equipments } \\
\text { used to gather data }\end{array}$ \\
\hline
\end{tabular}




\begin{tabular}{|l|l|l|}
\hline $\begin{array}{l}\text { Understanding the } \\
\text { Project }\end{array}$ & 5 & $\begin{array}{l}\text { (Each) Student's understanding of each step during } \\
\text { the implementation of the project. }\end{array}$ \\
\hline Quality of Display & 5 & Well organized display; project journal. \\
\hline
\end{tabular}

\section{Events}

The following events are common for all I-SWEEEP events since 2008. The information below is the events for I-SWEEEP 2009.

Judging Day: 220 judges from academia and professional companies interacted with contestants to evaluate their projects and propose new ideas to improve their research. Each project is evaluated by $8-10$ judges.

Public Visit Day: Around 2000 students and teachers from Greater Houston area visited ISWEEEP Fair. Students had a chance to meet top young researchers from all over the world and learned about their projects. Additionally, students enjoyed the science activities conducted by Texas A\&M University, Harmony School's Robotic teams, and the Houston Museum of Natural Science.

Field Trip Activities:

Field Trip to Space Center of Houston: 900 participants spent a half day at Space Center. Field Trip to the Houston Museum of Natural Science: 600 participants visited the museum. Rice University Program: The program is sponsored and organized by Shell Center for Sustainability at Rice University. 220 High school students participated in the event. Students had a chance to chat with college professors regarding their field of study and learn about sustainability studies at Rice University.

Social Night: Participants enjoyed the flag exchange program, folk dance, music, and traditional performances by visiting students' groups.

\section{Summary and Conclusion}

The Second Annual International Sustainable World Project Olympiad was completed successfully. The Cosmos Foundation, event organizer, presented Grand Awards at the award ceremony. The awards are valued at nearly $\$ 400,000$ in scholarships, monetary prizes, tuition grants, and scientific internships. The I-SWEEEP 2010 Olympiad will be held between April 14 and April 19, 2010. Within two years, this Olympiad has become very powerful program for bringing the world's young scientists together to focus on the sustainability issues. The ISWEEEP provided an unforgettable experience with great memories, interesting field-trips, multicultural exchanges, and new collaborations and relationships that will provide lifetime learning. Also, it is very obvious that I-SWEEEP experience is encouraging student a lot to improve their research, become more aware of the issues, and continue working on global problems.

I-SWEEEP 2010 will be held at Houston, as the energy capital of the world. The competition will again take place at the city's premier convention venue, the George R. Brown Convention Center in downtown Houston. Over 1000 highly qualified participants from all over the world will spend five days together in Houston to make the I-SWEEEP 2010 as an educational platform for sustainable future. Also, Greater Houston area students and public also will be 
invited to interact with these bright scientists and learn more on their brilliant solutions to globe's problems.

\section{Testimonials}

Below are the combinations of speeches made by state legislators, participants, professionals of energy, engineering, environment, science etc. before, during, and after I-SWEEEP Olympiad. Further testimonials can be found at the I-SWEEEP web site.

"I commend the organizers of this event (I-SWEEEP); your efforts will surely be part of the brick and mortar that develops an environmentally conscious community."

Rick Perry

Governor of Texas

"the I-SWEEEP students are going to be our future leaders, leading thinkers and scientists, and captains of industry that are going to transform the world."

Richard Johnson

Director of Sustainability

"...Before the I-SWEEEP, I have been telling people that this planet can only be saved by this young generation. At the I-SWEEEP, I met the kids who are really going to do it. I-SWEEEP was a spectacular success, and so supportive of so many young scientists from around the world, that I am confident that you inspired future world leaders, eminent researchers, teachers, and Nobel Prize winners."

Timothy D. Bechtel, Ph.D., P.G

Professor of Earth and Environmental Sciences

University of Pennsylvania

"I just wanted to take a moment to thank you for a wonderful I-SWEEEP. I can only begin to imagine the efforts that go into organizing such an event, and I hope you know what an amazing experience it was for all involved. This event is so powerful- bringing the world together to focus on sustainability issues, and affording the opportunity for them to excel at science."

Michelle Seeley-Flannory, New York

Elmont Memorial Science Research Coordinator

\section{References}

[1] Pecen R., \& Humston J. (2009). MSETI-AREA: Math-Science-Engineering Technology in Iowa on Applied Renewable Energy Areas. Proceedings of the ASEE 2009 Annual Conference and Exposition, AC 2009-2403. Austin, TX.

[2] United States Department of Education. ( September, 2000). Before it's too late: A report to the nation from the National Commission on Mathematics and Science Teaching for the 21st Century. Retrieved July 12, 2008, from http://www.ed.gov/inits/Math/glenn/report.pdf 
[3] Dugger, W.E., and Gilberti, A. F., Standards for Technological Literacy: Content for the Study of Technology, International Technology Education Association (ITEA), 2002

[4] Tims H., Turner G., Schillinger D., "IMELT: Integrating Mathematics, Engineering, and Literacy in the Teaching of Mathematics", Proceedings of ASEE, Annual Conference, June 2008.

[5] U.S. Department of Education, Institute of Education Sciences, National Center for Education Statistics, National Assessment of Educational Progress (NAEP), 1990-2007

Mathematics and Science Assessments. Accessed January, 52010.

[6] Science and Engineering Indicators 2006, Retrieved July 13, 2008, http://www.nsf.gov/statistics/seind06/

[7] Teach Eng. available at www.teachengineering.org. Hosted by National Science Digital Library. 2007

[8] Intel International Science and Engineering Fair, http://sciserv.org/isef/

[9] I-SWEEEP Online, http://www.isweeep.org/

[10] I-SWEEP 2009 Category Awards, http://www.isweep.org/index.php?option=com_content\&task=view\&id=75\&Itemid=83 